\title{
FAKTOR YANG BERHUBUNGAN DENGAN KEJADIAN HIPERTENSI DI PUSKESMAS POLONG BANGKENG UTARA KECAMATAN POLONG BANGKENG UTARA KABUPATEN TAKALAR
}

\author{
Musfirah $^{1,}$ dan A. Nur Hartati ${ }^{2}$ \\ S1 Kesehatan Masyarakat, Fakultas Kesehatan Masyarakat ${ }^{1,2}$ \\ Sekolah Tinggi Ilmu Kesehatan Tamalatea Makassar ${ }^{1,2}$ \\ musfirah@stiktamalateamks.ac.id ${ }^{1}$, a.nurhartati@stiktamalatea.ac.id ${ }^{2}$
}

\begin{abstract}
Hypertension has become a major public health problem in Indonesia as well as in several countries in the world. According to the WHO Hypertension is one of the most deadly diseases in the world. Hypertension is a disturbance in the blood vessels that lead to the supply of oxygen and nutrients below the obstructed blood to the tissues that need it. This study aims to determine the factors associated with hypertension in the Health Center of North District of pods Bangkeng North Bangkeng Takalar. Design of this study using cross sectional study design. Instruments used questionnaires, scales, medical records. The population in this study are all the people who come for treatment at the District Health Center of North Polong Bangkeng North Polong Bangkeng Takalar many as 1164 people and sample in this research using accidental sampling as many as 69 people.The data obtained is processed in the form of univariate analysis and bivariate analysis with $p$ value $=0.05$. The results showed that all the variables in meticulous shown to have a relationship with hypertension is obesity with $p$ value $=0.003$, physical activity with $p$ value $=0.002$, family history with $p$ value $=0.017$, cholesterol with $p$ value $=0.000$. Conclusion The results of this study showed that obesity, physical activity, family history and cholesterol have a relationship with hypertension.
\end{abstract}

Keywords $\quad$ : Cholesterol, Family History, Hypertension, Obesity, Physical Activity

\begin{abstract}
ABSTRAK
Penyakit hipertensi telah menjadi masalah utama dalam kesehatan masyarakat yang ada diIndonesia maupun dibeberapa negara yang ada didunia. Menurut WHO Hipertensi merupakan salah satu penyakit paling mematikan di dunia. Hipertensi adalah suatu gangguan pada pembulu darah yang mengakibatkan suplai oksigen dan nutrisi yang dibawah oleh darah terhambat ke jaringan tubuh yang membutuhkannya. Penelitian ini bertujuan untuk mengetahui faktor yang berhubungan dengan kejadian hipertensi di Puskesmas Polong Bangkeng Utara Kecamatan Polong Bangkeng Utara Kab. Takalar tahun.Desain penelitian ini menggunakan desain penelitian Cross sectional study. Instrumen yang digunakan Kuesioner, timbangan, rekan medis. Populasi dalam penelitian ini adalah seluruh masyarakat yang datang berobat di Puskesmas Polong Bangkeng Utara Kecamatan Polong Bangkeng Utara Kab. Takalar sebanyak 1164 orang dan sampel dalam penelitian ini menggunakan aksidental sampling yaitu sebanyak 69 orang. Data yang di peroleh diolah dalam bentuk analisis univariat dan analisis bivariate dengan $p$ value $=0.05$. Hasil penelitian ini menunjukkan bahwa semua variabel yang diteliti terbukti memiliki hubungan dengan kejadian hipertensi yaitu obesitas dengan $p$ value $=0.003$, aktivitas fisik dengan $p$ value $=0.002$, riwayat keluarga dengan $p$ value $=0.017$, kolesterol dengan $p$ value $=0.000$. Kesimpulan hasil penelitian ini menunjukkan bahwa obesitas, aktivitas fisik, riwayat keluarga dan kolesterol memiliki hubungan dengan kejadian hipertensi.
\end{abstract}

Kata Kunci : Aktivitas Fisik, Hipertensi, Kolesterol, Obesitas, Riwayat Keluarga

\section{PENDAHULUAN}

Hipertensi merupakan penyakit degeneratif yang menjadi masalah serius saat ini. Hipertensi dikategorikan sebagai the silent disease atau the silent killer karena penderita tidak mengetahui dirinya mengidap hipertensi atau tidak mengetahui sebelum memeriksakan tekanan darahnya. Insiden hipertensi meningkat seiring bertambahnya usia. Komplikasi hipertensi menyebabkan sekitar 9,4 kematian di seluruh dunia setiap tahunnya.Hipertensi 
menurut data dari World Health Organization (WHO), hipertensi menjadi penyebab $45 \%$ kematian akibat serangan jantung dan $51 \%$ akibat stroke diseluruh dunia.WHO menyebutkan negara berkembang memiliki penderita hipertensi sebesar $40 \%$ sedangkan negara maju hanya $35 \%$, kawasan Afrika memegang posisi tertinggi penderita hipertensi, yaitu sebesar 40\%. Kawasan Amerika sebesar 35\% dan Asia Tenggara 36\%. Kawasan Asia penyakit ini telah membunuh 1,5 juta orang setiap tahunnya. Sedangkan di Indonesia cukup tinggi, yakni mencapai $32 \%$ dari total jumlah penduduk.

Laporan Kemenkes (2013), bahwa hipertensi merupakan penyebab kematian nomor 3 setelah stroke dan tuberkulosis, dimana proporsi kematiannya mencapai $6,7 \%$ dari populasi kematian pada semua umur di Indonesia.Penderita hipertensi di Indonesia diperkirakan sebesar 15 juta tetapi hanya $4 \%$ yang hipertensi terkendali. Prevalensi hipertensi di Indonesia tahun 2015 kejadian hipertensi tertinggi di provinsi Sulawesi utara sebanyak $15.0 \%$, kemudian di ikuti Kalimantan selatan $13.1 \%$, Yogyakarta $12,8 \%$, Sulawesi tengah 11,6 gorontalo $11,1 \%$, jawa timur10,7\% , Kalimantan tengah $10.6 \%$, jawa barat $10,5 \%$, Kalimantan timur $10,5 \%$, dan Sulawesi selatan $10,3 \%$. Kemenkes RI (2018), profil data Kesehatan Indonesia menyebutkan bahwa prevalensi hipertensi penduduk umur $>18$ menurut karakteristik, umur 18-24 tahun sebanyak $13.2 \%$, umur 25-34 tahun sebanyak 20,1\%, umur 35-44 sebanyak 31,6 \%, umur 45-54 sebanyak 45,3\% tahun 55-64 sebanyak 55,2 \%, umur 65-74 tahun sebanyak 63,2\%, 75+ tahun sebanyak 69,5.Di Sulawesi selatan berdasarkan hasil Riskesdas tahun 2014 dari 23 kabupaten/kota prevalensi penyakit Hipertensi mencapai $28,1 \%$ (riskesdas 2014).

Angka kejadian Hipertensi Di Sulawesi selatan tahun 2015 tertinggi di kabupaten gowa sebanyak 27,514,diikuti kabupaten jeneponto sebanyak 22,514, kabupaten pinrang sebanyak 17,742,Enrekang sebanyak 13,504 dan di kabupaten soppeng sebanyak 13,435. Menurut data Dinas Kesehatan takalar tahun 2018 hipertensi masuk dalam daftar 10 penyakit tertinggi dengan kasus sebanyak 12,645 kasus, puskesmas polong bangkeng utara kecamatan polong bangkeng utara Kab. Takalar pada tahun 2016 sebanyak 499, tahun 2017 sebanyak 509 dan tahun 2018 sebanyak 1478.

Hipertensi membutuhkan penanganan dengan cara pencegahan agar penderita hipertensi tidak mengalami komplikasi dari penyakit hipertensi yang diderita. Pencegahan hipertensi dapat dilakukan dengan memprediksi besarnya resiko seseorang terkena hipertensi, seperti obesitas, aktifitas fisik, riwayat keluarga dan kolesterol sehingga dapat dijadikan pengambilan keputusan mengatasi persoalan hipertensi dalam upaya pencegahan sejak dini agar angka kesakitan dan kematian hipertensi menurun.

Penelitian ini menganalisis hubungan obesitas, menganalisis hubungan aktivitas fisik, menganalisis hubungan riwayat keluarga, menganalisis hubungan kolesterol yang dapat dijadikan indikator kejadian hipertensi di puskesmas polong bangkeng utara kecamatan polong bangkeng utara kabupaten takalar. Meskipun belum ada kebaruan dalam penelitian ini, namun melihat tingginya angka kejadian hipertensi sehingga peneliti tertarik untuk melakukan penelitian dengan tujuan memprediksi besarnya resiko seseorang terkena hipertensi, sehingga dapat dijadikan pengambilan keputusan mengatasi persoalan hipertensi dalam upaya pencegahan sejak dini agar angka kesakitan dan kematian hipertensi menurun.

\section{METODE}

Penelitian metode survei analitik dengan menggunakan pendekatan cross sectional study. Populasi dalam penelitian sebanyak 1164 responden, dengan teknik pengambilan sampel Eksidental sampling sebanyak 64 responden dengan rumus 
Lameshow. Jenis data yang digunakan dalam dalam penelitian ini yaitu data primer dan data sekunder. Data primer diperoleh melalui wawancara menggunakan kuesioner. Data sekunder tentang kejadian hipertensi diperoleh dari cacatan rekam medik di puskesmas Polong Bangkeng Utara

Tahap pengolahan data berupa editing,coding, entri data, dan tabulating. Data dianalisis diinterprestasikan untuk menguji hipotesis yang diajukan. Analisis bivariat digunakan untuk mengetahui hubungan dari masing-masing variabel baik variabel bebas maupun variabel terikat uji statistik dengan menggunakan uji pearson chi-square.

\section{HASIL}

\begin{tabular}{|c|c|c|}
\hline $\begin{array}{l}\text { Distribusi } \\
\text { Responden }\end{array}$ & Frekuensi & Karakteristik \\
\hline Tabel $\quad 1$. & $\begin{array}{l}\text { Karakteristi } \\
\text { berdasarkan } \\
\text { Kelamin, P } \\
\text { Pekerjaan }\end{array}$ & $\begin{array}{l}\text { k Responden } \\
\text { n Umur, Jenis } \\
\text { Pendidikan dan }\end{array}$ \\
\hline \multirow[t]{2}{*}{ Karakteristik } & Jumlah & \\
\hline & Frekuensi & $\%$ \\
\hline \multicolumn{3}{|l|}{ Umur } \\
\hline $20-29$ & 3 & 4,3 \\
\hline $30-39$ & 10 & 14,5 \\
\hline $40-49$ & 20 & 29,0 \\
\hline $50-59$ & 17 & 24,6 \\
\hline$>60$ & 19 & 27,5 \\
\hline \multicolumn{3}{|l|}{ Jenis Kelamin } \\
\hline Laki-laki & 17 & 24,6 \\
\hline Perempuan & 52 & 75,4 \\
\hline \multicolumn{3}{|l|}{ Pendidikan } \\
\hline Tidak sekolah & 1 & 1,4 \\
\hline SD & 15 & 21,7 \\
\hline SMP & 25 & 36,2 \\
\hline SMA & 25 & 36,2 \\
\hline PT & 3 & 4,3 \\
\hline \multicolumn{3}{|l|}{ Pekerjaan } \\
\hline Tidak bekerja & 13 & 18,8 \\
\hline IRT & 39 & 56,5 \\
\hline Petani & 10 & 14,5 \\
\hline Mebel & 3 & 4,3 \\
\hline PNS & 4 & 5,8 \\
\hline
\end{tabular}

Karakteristik responden berdasarkan umur, jenis kelamin, pendidikan dan pekerjaan ditunjukkan pada (Tabel 1). Umur responden $(29,0 \%)$ termasuk pada rentang umur 40-49 tahun. Jenis kelamin Sebagian besar perempuan (75,45\%), Pendidikan responden Sebagian besar pada tingkat Pendidikan SMP dan SMA $(36,2 \%)$ dan Pekerjaan responden Sebagian besar berprofesi sebagai ibu rumah tangga $(56,5 \%)$.

Distribusi Frekuesi Berdasarkan Kejadian Hipertensi

Tabel 2. Distribusi Frekuensi Berdasarkan Kejadian Hipertensi Di Puskesmas Polong Bangkeng Utara Kecamatan Polong Bangkeng Utara Kab. Takalar

\begin{tabular}{lll}
\hline Hipertensi & Frekuensi & \% \\
\hline Ya & 46 & 66,7 \\
Tidak & 23 & 33,3 \\
\hline Total & 69 & 100,0 \\
\hline
\end{tabular}

Berdasarkan tabel 2 diketahui bahwa 46 responden $(66,7 \%)$ termasuk pada kategori menderita hipertensi.

\section{Distribusi Frekuesi Berdasarkan} Kejadian Obesitas

Tabel 3. Distribusi Frekuensi Berdasarkan Obesitas Di Puskesmas Polong Bangkeng Utara Kecamatan Polong Bangkeng Utara Kab. Takalar

\begin{tabular}{lll}
\hline Obesitas & Frekuensi & \% \\
\hline Ya & 41 & 59,4 \\
Tidak & 28 & 40,6 \\
\hline Total & 69 & 100,0 \\
\hline
\end{tabular}

Berdasarkan tabel 3 diketahui bahwa 41 responden $(59,4 \%)$ termasuk pada kategori obesitas

\section{Distribusi Frekuesi Berdasarkan Aktifitas Fisik}

Tabel 4. Distribusi Frekuensi Berdasarkan Aktifitas Fisik Di Puskesmas Polong Bangkeng Utara Kecamatan Polong Bangkeng Utara Kab. Takalar 


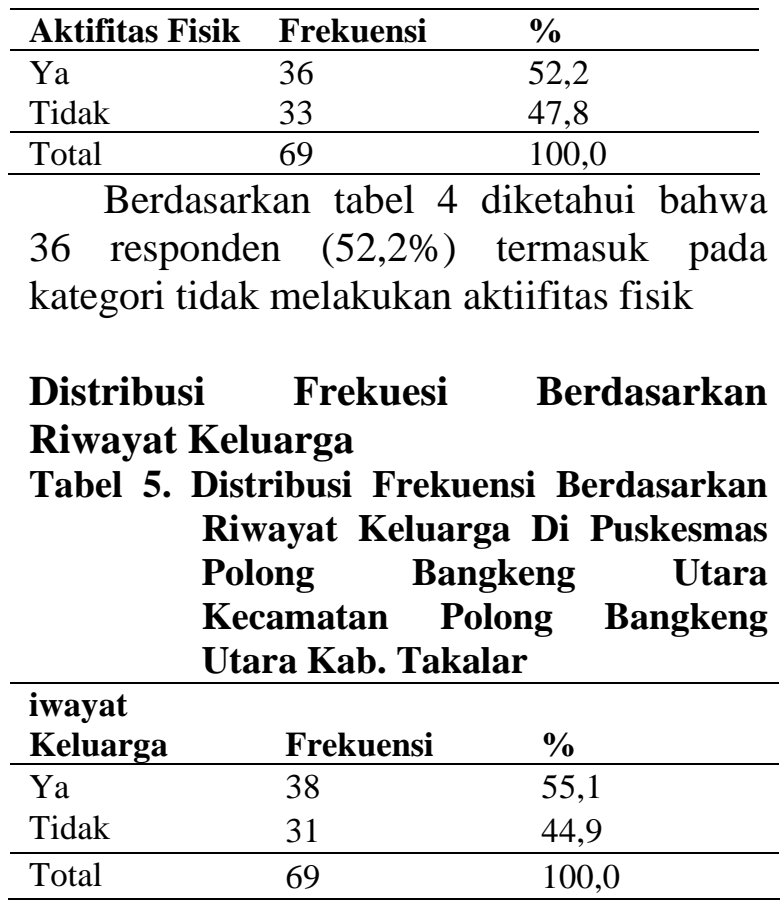

Berdasarkan tabel 5 diketahui bahwa 38 responden $(55,1 \%)$ termasuk pada kategori kelurga yang memiliki Riwayat keluarga dengan hipertensi

\section{Distribusi Frekuesi Berdasarkan}

Kolesterol

Tabel 6. Distribusi Frekuensi Berdasarkan Kolesterol Di Puskesmas Polong Bangkeng Utara Kecamatan Polong Bangkeng Utara Kab. Takalar

\begin{tabular}{lll}
\hline Kolesterol & Frekuensi & \% \\
\hline Ya & 33 & 47,8 \\
Tidak & 36 & 52,2 \\
\hline Total & 69 & 100,0 \\
\hline
\end{tabular}

Berdasarkan tabel 6 diketahui bahwa 36 responden $(52,2 \%)$ termasuk pada kategori kelurga yang memiliki kolesterol.

Hubungan Obesitas Dengan Kejadian Hipertensi

Tabel 7. Hubungan Obesitas Dengan Kejadian Hipertensi Di Puskesmas Polong Bangkeng Utara Kecamatan Polong Bangkeng Utara Kab. Takalar

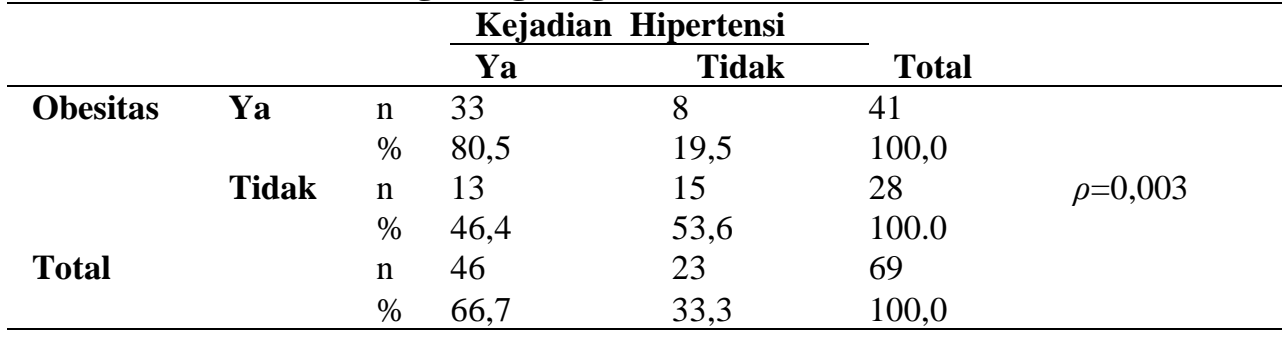

Hasil analisis obesitas dengan kejadian hipertensi menunjukkan bahwa dari 41 responden yang mengalami obesitas, terdapat 33 responden $(80,5 \%)$ yang menderita hipertensi dan 8 responden $(19,5 \%)$ yang tidak menderita hipertensi.
Dari hasil uji statistik dengan menggunakan uji pearson chi-square diperoleh nilai $\rho=0,003$ dimana $\rho<\alpha$ $(\alpha=0,05)$ maka Ho ditolak, berarti ada hubungan bermakna antara obesitas dengan kejadian hipertensi

\section{Hubungan Aktifitas Fisik Dengan Kejadian Hipertensi}

Tabel 8 Hubungan Aktifitas Fisik Dengan Kejadian Hipertensi Di Puskesmas Polong Bangkeng Utara Kecamatan Polong Bangkeng Utara Kab. Takalar

\begin{tabular}{lllllll}
\hline & & \multicolumn{2}{c}{ Kejadian } & hipertensi & & \\
& & & Ya & Tidak & Total & \\
\hline Aktifitas fisik & Ya & $\mathrm{n}$ & 18 & 18 & 36 & \\
& & $\%$ & 50,0 & 50,0 & 100,0 & \\
& \multirow{2}{*}{ Tidak } & $\mathrm{n}$ & 28 & 5 & 33 & $\rho=0,002$ \\
& & $\%$ & 84,8 & 15,2 & 100,0 & \\
& & $\mathrm{n}$ & 46 & 23 & 69 & \\
& & $\%$ & 66,7 & 33,3 & 100,0 & \\
\hline
\end{tabular}


Berdasarkan hasil analisis Aktivitas fisik dengan kejadian hipertensi pada tabel 8 menunjukkan bahwa dari 36 responden yang melakukan aktifitas fisik, terdapat 18 responden $(50,0 \%)$ yang menderita hipertensi dan 18 responden $(50,0 \%)$ yang tidak menderita hipertensi.
Dari hasil uji statistik dengan menggunakan uji pearson chi-square diperoleh nilai $\rho=0,002$ dimana $\rho<\alpha$ $(\alpha=0,05)$ maka Ho ditolak, berarti ada hubungan bermakna antara aktifitas fisik dengan kejadian hipertensi.

\section{Hubungan Riwayat Keluarga Dengan Kejadian Hipertensi}

Tabel 9 Hubungan Riwayat Keluarga Dengan Kejadian Hipertensi Di Puskesmas Polong Bangkeng Utara Kecamatan Polong Bangkeng Utara Kab. Takalar

\begin{tabular}{|c|c|c|c|c|c|c|}
\hline & & & \multicolumn{2}{|c|}{ Kejadian hipertensi } & \multirow[b]{2}{*}{ Total } & \\
\hline & & & $\mathbf{Y a}$ & Tidak & & \\
\hline \multirow[t]{4}{*}{ Riwayat keluarga } & Ya & $\mathrm{n}$ & 30 & 8 & 38 & \\
\hline & & $\%$ & 78,9 & 21,1 & 100,0 & \\
\hline & Tidak & $\mathrm{n}$ & 16 & 15 & 31 & $\rho=0,017$ \\
\hline & & $\%$ & 51,6 & 48,4 & 100,0 & \\
\hline \multirow[t]{2}{*}{ Total } & & $\mathrm{n}$ & 46 & 23 & 69 & \\
\hline & & $\%$ & 66,7 & 33,3 & 100,0 & \\
\hline
\end{tabular}

Berdasarkan hasil analisis Riwayat keluarga dengan kejadian hipertensi menunjukkan bahwa dari 38 responden yang memiliki riwayat keluarga, terdapat 30 responden $(78,9 \%)$ yang menderita hipertensi dan 8 responden $(21,1 \%)$ yang tidak menderita hipertensi.

\section{Hbungan Kolesterol Dengan Kejadian Hipertensi}

Tabel 10 Hubungan Kolesterol Dengan Kejadian Hipertensi Di Puskesmas Polong Bangkeng Utara Kecamatan Polong Bangkeng Utara Kab. Takalar

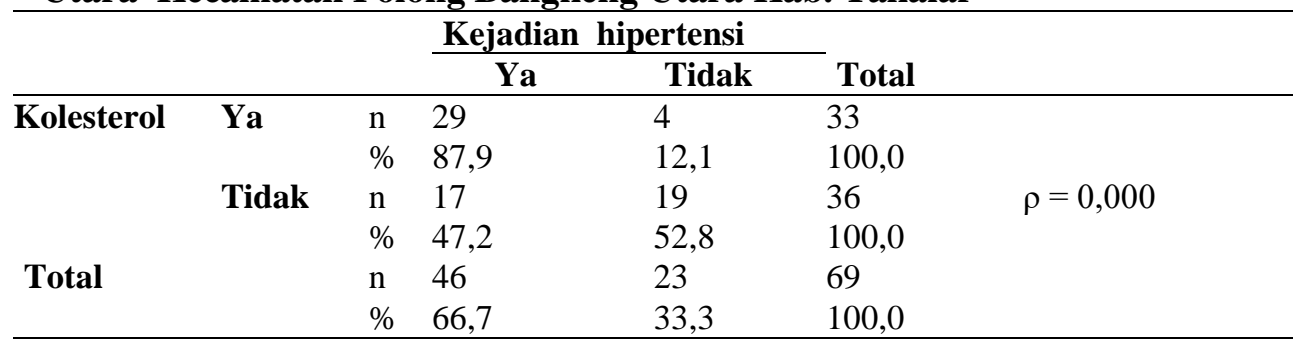

Berdasarkan hasil analisis kolesterol dengan kejadian hipertensi menunjukkan bahwa 36 responden yang memiliki kolesterol normal terdapat 17 responden $(42,7 \%)$ menderita hipertensi dan 19 responden $(52,8 \%)$ yang tidak menderita hipertensi.

Dari hasil uji statistik dengan menggunakan uji pearson chi-square diperoleh nilai $\rho=0,000$ dimana $\rho<\alpha$ $(\alpha=0,05)$ maka Ho ditolak, berarti ada hubungan bermakna antara Riwayat keluarga dengan kejadian hipertensi.

\section{PEMBAHASAN}

\section{Hubungan Obesitas Dengan Kejadian Hipertensi}

Obesitas adalah keadaan dimana terjadi penimbunan lemak berlebih dalam jaringan tubuh. Seseorang yang mengalami obesitas atau kegemukan memiliki resiko besar untuk mengalami prehipertensi dan hipertensi. Indikator yang bisa di gunakan 
untuk menentukan ada dan tidak ada obesitas pada seseorang adalah melalui pengukuran IMT atau lingkar perut. Meskipun demikian, kedua indiator tersebut bukanlah indikator terbaik untuk menentukan terjadinya hipertensi, tetapi menjadi salah satu faktor resiko yang dapat mempercepat kejadian hipertensi. Hasil analisis obesitas dengan kejadian hipertensi menunjukkan bahwa dari 41 responden yang mengalami obesitas, terdapat 33 responden $(80,5 \%)$ yang menderita hipertensi dan 8 responden $(19,5 \%)$ yang tidak menderita hipertensi. Sedangkan 28 responden yang tidak mengalami obesitas terdapat 13 responden $(46,4 \%)$ yang menderita hipertensi dan 15 responden $(53,6 \%)$ yang tidak menderita hipertensi.

Hasil penelitian menunjukkan bahwa responden yang obesitas cenderung menderita hipertensi, hal ini di sebabkan karena obesitas menyebabkan penimbunan lemak berlebih didalam jaringan tubuh sehingga jantung secara otomatis harus memompa darah lebih keras ke seluruh tubuh dan tekanan darah meningkat, sedangkan responden yang tidak obesitas tetapi menderita hipertensi hal ini di sebabkan karena faktor umur, ketika umur 45 tahun ke atas dinding arteri akan mengalami penebalan karena penumpukan zat kolagen pada lapisan otot, sehingga pembuluh darah menyempit dan menjadi kaku sehingga menyebabkan tekanan darah meningkat.

Penelitian ini sejalan dengan penelitian yang dilakukan oleh Teguh Dika Rohkuswara (2016) tentang hubungan obesitas dengan kejadian hipertensi derajat 1 di pos pembinaan terpadu penyakit tidak menular (posbindu PTM) Kantor Kesehatan Pelabuhan Bandung tahun 2016, yang mengatakan bahwa diketahui hubungan obesitas dengan hipertensi derajat 1 sebesar 1,681 artinya responden dengan obesitas memiliki resiko sebesar 1,681 kali untuk menderita hipertensi dibandingkan dengan yang tidak obesitas.

Hasil penelitian ini tidak sejalan dengan penelitian yang di lakukan oleh
Budi artiyaningrum (2014) tentang faktorfaktor yang berhubungan dengan kejadian hipertensi tidak terkendali pada penderita yang melakukan pemeriksaan rutin di Puskesmas Kedung mundu Kota Semarang tahun 2014, yang mengatakan bahwa berdasarkan hasil uji statistik dengan menggunakan uji chi square di peroleh nilai probabilitas ( $p$ value ) sebesar $\rho=0,280$ dengan tingkat kesalahan $\alpha=0.05$. Hal ini mebuktikan bahwa tidak ada hubungan antara obesitas dengan kejadian hipertensi.

\section{Hubungan Aktifitas Fisik Dengan Kejadian Hipertensi.}

Aktivitas fisik dapat didefinisikan sebagai pergerakan otot yang menggunakan energi. Olahraga adalah salah satu jenis aktivitas fisik yang didefinisikan sebagai aktivitas yang direncanakan dan diberi struktur dimana gerakan bagian tubuh diulang untuk memperoleh kebugaran, misalnya jalan kaki, jogging, berenang dan aerobik. Secara substansial kegiatan olahraga dengan intensitas sedang lebih baik daripada olahraga dengan intensitas berat. Hal tersebut dikarenakan dapat meningkatkan cardiak output dengan sedikit kenaikan tekanan darah. Pada dasarnya setiap orang dewasa harus melakukan paling sedikit 30 menit aktivitas fisik dengan intensitas sedang setiap hari.

Aktivitas fisik yang teratur membantu meningkatkan efisiensi jantung secara keseluruhan. Mereka yang secara fisik aktif umumnya mempunyai tekanan darah yang lebih rendah dan lebih jarang terkena tekanan darah tinggi. Mereka yang secara fisik aktif cenderung untuk mempunyai fungsi otot dan sendi yang lebih baik, karena organ-organ tersebut lebih kuat dan lebih lentur. Aktivitas yang berupa gerakan atau latihan aerobik bermanfaat untuk meningkatkan dan mempertahankan kebugaran, ketahanan kardio-respirator.

Kurangnya aktivitas fisik meningkatkan resiko menderita hipertensi. Orang yang tidak aktif beraktivitas fisik cenderung mempunyai frekuensi denyut jantung yang lebih tinggi sehingga otot 
jantungnya harus bekerja lebih keras pada setiap kontraksi, semakin besar dan sering otot jantung memompa, maka semakin besar tekanan yang dibebankan pada arteri sehingga tekanan darah akan meningkat.

Aktifitas fisik sangat mempengaruhi stabilitas tekanan darah. Pada orang yang tidak aktif melakukan kegiatan fisik cenderung mempunyai denyut jantung yang lebih tinggi. Hal tersebut mengakibatkan otot jantung bekerja lebih keras lagi pada kontraksi. Aktifitas fisik membantu seseorang mengontrol berat badan. aktifitas fisik yang dilakukan rutin selama 30-45 menit setiap hari akan membantu mengontrol tekanan darah.

Berdasarkan hasil analisis Aktivitas fisik dengan kejadian hipertensi menunjukkan bahwa dari 36 responden yang melakukan aktifitas fisik, terdapat 18 responden $(50,0 \%)$ menderita hipertensi dan 18 responden $(50,0 \%)$ yang tidak menderita hipertensi. Sedangkan 33 responden yang tidak melakukan aktifitas fisik terdapat 28 responden $(84,8 \%)$ menderita hipertensi dan 5 responden $(15,2 \%)$ yang tidak menderita hipertensi. Hasil penelitian menunjukkan responden yang memiliki aktivitas fisik kurang cenderung menderita hipertensi hal ini disebabkan karena aktivitas fisik yang kurang bisa menyebabkan penumpukan lemak di dalam pembuluh darah sehingga jantung akan bekerja lebih keras dan menyebabkan resiko tekanan darah meningkat, sedangkan responden yang memiliki aktivitas cukup namun menderita hipertensi, hal ini disebabkan karena faktor lain seperti gaya hidup yang tidak sehat sehingga menyebabkan tekanan darah darah meningkat. Dari hasil uji statistik dengan menggunakan uji pearson chi-square diperoleh nilai $\rho=0,002$ dimana $\rho<\alpha$ $(\alpha=0,05)$ maka Ho ditolak dan Ha diterima yang berarti ada hubungan bermakna antara aktifitas fisik dengan kejadian hipertensi.

Penelitian ini sejalan dengan penelitian yang di lakukan oleh Muhammad Hafiz, dkk (2016) tentang faktor-faktor yang berhubungan dengan kejadian hipertensi pada kelompok lanjut usia di Wilayah Kerja UPT Puskesmas Petang I Kabupaten Badung, yang mengatakan bahwa berdasarkan hasil uji statistic dengan menggunakan uji chi square di peroleh nilai probabilitas ( $p$ value ) sebesar $\rho=0,017$ dengan tingkat kesalahan $\alpha=0,05$. Hal ini membuktikan bahwa ada hubungan antara Aktifitas fisik dengan kejadian hipertensi. Karena berdasarkan penelitian yang dilakukan orang yang memiliki aktifitas fisik kurang beresiko lebih tinggi terkena hipertensi.

Hasil Penelitian ini tidak sejalan dengan penelitian yang dilakukan oleh Tri Novitaningtyas (2014), tentang Hubungan Karakteristik (Umur, Jenis Kelamin, Tingkat Pendidikan) Dan Aktivitas Fisik Dengan Tekanan Darah Pada Lansia Di Kelurahan Makamhaji Kecamatan Kartasura Kabupaten Sukoharjo, menunjukkan bahwa berdasarkan pengukuran tekanan darah sistoliknya, lansia yang memiliki aktivitas fisik ringan cenderung mengalami hipertensi daripada lansia yang memiliki aktifitas sedang. Terdapat $46 \%$ subjek yang termasuk dalam kategori aktivitas fisik ringan yang menderita hipertensi. Lansia yang aktifitas fisiknya sedang tekanan darahnya cenderung dalam kategori normal, 100\% subjek yang aktifitas fisiknya sedang tekanan darahnya termasuk dalam kategori normal. Hasil uji statistik yang dilakukan dengan mengunakan uji Rank Spearman diperoleh nilai $\mathrm{p}$ sebesar 0,538 ( $\mathrm{p}>0,05)$, maka H0 diterima sehingga tidak terdapat hubungan antara aktivitas fisik dengan tekanan darah sistolik pada lansia di Kelurahan Makamhaji.

\section{Hubungan Riwayat Keluarga Dengan Kejadian Hipertensi}

Secara genetik, penyakit hipertensi memiliki hubungan yang erat dengan gengen pemicu hipertensi yang terdapat di dalam kromosom manusia. Sekalipun gengen Hipertensi belum bisa diidentifikasikan secara akurat, namun faktor-faktor genetik yang terdapat di gen manusia sangat 
mempengaruhi system renin-angiotensinaldosterone. Adanya faktor genetik pada keluarga tertentu yang dapat menyebabkan keluarga beresiko menderita hipertensi. Orang yang memiliki riwayat keluarga hipertensi memiliki risiko dua kali lebih besar dibandingkan orang yang tidak memiliki keluarga dengan riwayat hipertensi.

Hasil analisis Riwayat keluarga dengan kejadian hipertensi menunjukkan bahwa dari 38 responden yang memiliki riwayat keluarga, terdapat 30 responden $(78,9 \%)$ yang menderita hipertensi dan 8 responden $(21,1 \%)$ yang tidak menderita hipertensi. Sedangkan 31 responden yang tidak memiliki riwayat keluarga terdapat 16 responden $(51,6 \%)$ menderita hipertensi dan 15 responden $(48,4 \%)$ yang tidak menderita hipertensi. Hasil penelitian menunjukan responden yang memiliki riwayat keluarga cenderung menderita hipertensi, sedangkan responden yang tidak memiliki riwayat keluarga namun menderita hipertensi, hal ini disebabkan oleh banyak faktor seperti pola hidup yang tidak sehat sehingga menyebabkan elastisitas pembuluh darah menurun, katup jantung menebal dan menjadi kaku, kemampuan jantung memompa darah menurun $1 \%$ setiap tahun setelah berumur 20 tahun. Kemampuan jantung memompa darah menurun menyebabkan menurunnya kontraksi dan volumenya kehilangan elastisitas pembuluh darah.

Hasil penelitian ini sejalan dengan penelitian yang dilakukan oleh Sartik, dkk (2017) tentang faktor - faktor risiko dan angka kejadian hipertensi pada penduduk Palembang, yang mengatakan bahwa berdasarkan hasil uji statistic dengan menggunakan uji chi square di peroleh nilai probabilitas ( $p$ value) sebesar $\rho=0,000$ dengan tingkat kesalahan $\alpha=0,05$. Hal ini membuktikan bahwa terdapat hubungan antara Riwayat keluarga dengan kejadian hipertensi. Hasil penelitian ini membuktikan bahwa faktor keturunan memiliki pernanan penting dan menjadi penentu orang untuk menderita hipertensi, dan bila dibiarkan secara alami tanpa intervensi apapun, maka bersama lingkungannya akan menyebabkan hipertensi hingga menimbulkan tanda dan gejalah. Mengetahui orang tua menderita hipertensi sebaiknya rutin memeriksakan tekanan darah dan menghindari gaya hidup tidak sehat yang dapat meningkatkan tekanan darah.

Hasil penelitian ini tidak sejalan dengan penelitian yang dilakukan oleh Dwi Sapta Aryantiningsih (2018), Hipertensi Pada Masyarakat Di Wilayah Kerja Puskesmas Harapan Raya Pekanbaru, yang mengatakan bahwa pada kelompok kasus responden yang memiliki riwayat keluarga berisiko (ada riwayat hipertensi) sebanyak 22 orang responden $(37,9 \%)$ lebih banyak dibandingkan pada kelompok kontrol. Hasil uji statistik diperoleh nilai Pvalue $=0,160$ berarti nilai $\mathrm{P}>0,05$ dengan demikian dapat disimpulkan bahwa tidak ada hubungan yang signifikan antara riwayat keluarga dengan hipertensi.

\section{Hubungan Kolesterol dengan Kejadian Hipertensi}

Kolesterol tinggi (hiperkolesterolemia) akan menimbulkan masalah terutama pada pembuluh darah dan otak. Jika kadar kolesterol melebihi batas normal akan menyebabkan aterosklerosis. Aterosklerosis akan menyumbat pembuluh darah arteri. Dinding - dinding pada saluran arteri yang mengalami arterosklerosis akan menjadi tebal, kaku karena tumpukan kolesterol, saluran arteri mengalami proses penyempitan, pengerasan, kehilangan kelenturannya dan menjadi kaku. Berbagai penelitian epidemiologi, biokimia maupun eksperimental menyatakan bahwa yang memegang peranan penting terhadap terbentuknya aterosklerosis adalah kolesterol. Apabila sel sel otot arteri tertimbun lemak maka elastisistasnya akan menghilang dan berkurang dalam mengatur tekanan darah sehingga akan terjadi berbagai penyakit seperti hipertensi, aritmia, stroke, dan lain -lain. 
Kolesterol merupakan faktor resiko yang dapat dirubah dari hipertensi, jadi semakin tinggi kadar kolesterol total maka akan semakin tinggi kemungkinan terjadinya hipertensi. Peningkatan kadar kolesterol darah banyak di alami oleh penderita hipertensi, pernyataan ini diperkuat dengan berbagai penelitian yang mendukung. Di Amerika penelitian jantung Framingham menyatakan hubungan antara kadar kolesterol dengan tekanan darah. Hipertensi berhubungan dengan abnormalitas lipid kolesterol total, dimana kehadiran dislipidemia meningkatkan risiko terjadinya hipertensi. Kadar total kolesterol serum meningkat sesuai dengan peningkatan tekanan darah. Konsentrasi serum pada penderita hipertensi lebih tinggi dari pada serum normotensif mengindikasikan risiko komplikasi kardiovaskuler dan cerebrovaskuler yang lebih besar seperti penyakit jantung koroner dan stroke pada pasien hipertensi dengan kadar kolesterol tinggi.

Meningkatnya tekanan darah didalam arteri bisa terjadi melalui beberapa cara yaitu jantung memompa lebih kuat sehingga mengalirkan lebih banyak cairan pada setiap detiknya arteri besar kehilangan kelenturannya dan menjadi kaku sehingga mereka tidak dapat mengembang pada saat jantung memompa darah melalui arteri tersebut. Darah pada setiap denyut jantung dipaksa untuk melalui pembuluh yang sempit dari pada biasanya dan menyebabkan naiknya tekanan. Inilah yang terjadi pada usia lanjut, dimana dinding arteri telah menebal dan kaku karena arteriosklerosis. Arteriosklerosis atau pengerasan arteri akan menyebabkan penurunan kelenturan arteri yang terpengaruhi. Simpanan lemak menghalangi aliran darah yang melalui arteri tersebut. Kedua faktor tersebut cenderung meningkatkan tekanan darah.

Hasil analisis kolesterol dengan kejadian hipertensi menunjukkan bahwa dari 33 responden yang memiliki kolesterol tinggi, terdapat 29 responden $(87,9 \%)$ yang menderita hipertensi dan 4 responden
$(12,1 \%)$ yang tidak menderita hipertensi. Sedangkan 36 responden yang memiliki kolesterol normal terdapat 17 responden $(42,7 \%)$ yang menderita hipertensi dan 19 responden $(52,8 \%)$ yang tidak menderita hipertensi. Hasil penelitian ini menunjukkan bahwa responden yang memiliki kolesterol lebih beresiko menderita hipertensi karena kadar kolesterol yang tinggi di dalam darah bisa membentuk bekuan dan plak yang dapat menyumbat arteri dan menyebabkan aliran darah ke jantung terputus. sedangkan responden yang memiliki kolesterol normal namun menderita hipertensi, hal ini disebabkan karena faktor umur, ketika umur 45 tahun dinding arteri akan mengalami penebalan oleh karena penumpukan zat kolagen pada lapisan otot, sehingga pembuluh dara akan menyempit dan menjadi kaku hal ini menyebabkan jantung akan bekerja lebih keras untuk memompa darah sehingga menyebabkan tekanan darah meningkat.

Kolesterol yang ada dalam darah semakin lama semakin menebal. Semakin bertambah usia, penebalan yang terjadi akan semakin banyak. Orang yang berusia lanjut memiliki kadar kolesterol yang berlebih sehingga resiko terkena kolesterol tinggipun semakin besar. Menurut sebuah organisasi kolesterol dikatakan bahwa pria yang berusia di atas 45 tahun dan perempuan di atas 55 tahun akan semakin tinggi memiliki kolesterol tinggi.

Kolesterol tidak menimbulkan dampak buruk yang perlu diwaspadai, termasuk sebagai pemicu kenaikan tekanan darah. kolesterol akan menjadi bermasalah jika teroksidasi. Kolesterol yang teroksidasi adalah kolesterol Low Density Lipoprotein (LDL), kolestrol LDL mengangkut kolesterol dari hati, tempatnya dproduksi, ke jaringan tubuh yang memerlukan. LDL merupakan transporter kolesterol terbanyak dalam darah. Jika terdapat terlalu banyak kolesterol LDL yang bersirkulasi dalam aliran darah, semakin lama LDL akan menumpuk dibagian dinding arteri yang memasok organ tubuh dengan oksigen dan 
nutrisi. Penumpukan kolesterol LDL ini dapat mempersempit dan menyumbat arteri melalui pembentukan atroma sehingga kelenturan arteri akan menurun. Kondisi seperti inilah yang membuat tekanan di arteri meningkat atau dinamakan tekanan darah tinggi, sehingga tidak semua jenis kolesterol yang akan meningkatkan tekanan darah.

Hal ini sesuai dengan teori yang menyatakan bahwa kolesterol yang ada dalam darah semakin lama semakin menebal. Semakin bertambah usia, penebalan yang terjadi akan semakin banyak. Orang yang berusia lanjut memiliki kadar kolesterol yang berlebih sehingga resiko terkena kolesterol tinggipun semakin besar. Menurut sebuah organisasi kolesterol dikatakan bahwa pria yang berusia di atas 45 tahun dan perempuan di atas 55 tahun akan semakin tinggi memiliki kolesterol tinggi.

Hasil penelitian ini sejalan dengan penelitian yang dilakukan oleh Heny maryati (2017) tentang hubungan kadar kolesterol dengan tekanan darah penderita hipertensi di Dusun Sidomulyo Desa Rejoagung Kecamatan Ploso Kabupaten Jombang, yang mengatakan bahwa berdasarkan hasil uji statistik dengan menggunakan uji chi square di peroleh nilai probabilitas ( $p$ value ) sebesar $\rho=0,000$ dengan tingkat kesalahan $\alpha=0,05$. Hal ini mebuktikan bahwa terdapat hubungan antara Riwayat keluarga dengan kejadian hipertensi.

Hasil penelitian ini tidak sejalan dengan penelitian yang dilakukan oleh Tina widihatul Lestari (2015) , tentang Hubungan Kadar Kolesterol Dengan Tekanan Darah Pada Pra Lansia Hipertensi Di Posyandu Lansia Dusun Jetis Bantul Yogyakarta, dapat diketahui bahwa hasil analisis dengan uji Spearman Rank, diperoleh nila $\mathrm{p}$ value sebesar 0,954 dengan koefisien korelasi sebesar -.011. Oleh karena $\mathrm{p}$ value lebih besar dari 0,05 (sig> 0,05), maka hal ini berarti Ho diterima dan Ha ditolak, artinya tidak ada hubungan antara kadar kolesterol dengan tekanan darah pra lansia hipertensi di Posyandu Lansia Dusun Jetis Bantul Yogyakarta. Interpretasi nilai korelasi -.011 menunjukkan bahwa tingkat hubungan sangat rendah dengan hubungan yang berlawanan arah (negatif), sehingga semakin besar nilai suatu variabel maka semakin kecil nilai variabelnya. Disimpulkan bahwa tidak ada hubungan yang signifikan antara kadar kolesterol dengan tekanan darah.

\section{KESIMPULAN}

Berdasarkan hasil penelitian tersebut dapat diketahui bahwa Responden yang mengalami obesitas cenderung lebih tinggi memiliki risiko untuk menderita hipertensi, Responden yang mempunyai aktifitas fisik cencerung besar berisiko terkena hipertensi, begitun sebaliknya responden yang memiliki aktivitas fisik berat lebih sedikit berisiko terkena hipertensi, Responden kemungkinan lebih besar untuk mendapatkan hipertensi jika orang tuanya menderita hipertensi dan Responden yang memiliki kadar kolesterol yang berlebih tinggi menyebabkan penyempitan dan terjadi penyumbatan arteri sehingga kondisi seperti ini yang membuat tekanan di arteri meningkat sehingga menyebabkan tekana darah tinggi.

\section{UCAPAN TERIMA KASIH}

Peneliti mengucapkan terima kasih kepada Kementerian Riset dan Teknologi Republik Indonesia atas bantuan dana hibah penelitian dosen pemula untuk semua proses pelaksanaan penelitian ini. terima kasih juga kepada kepala puskesmas, staf dan masyarakat di wilayah Puskesmas Polong Bangkeng Utara Kabupaten Takalar. 


\section{DAFTAR PUSTAKA}

Almina Rospitaria Tarigan1, Z.L., Syarifah3,(2017). Pengaruh Pengetahuan, Sikap Dan Dukungan Keluarga Terhadap Diet Hipertensi Di Desa Hulu Kecamatan Pancur Batu Tahun 2016. Vol 11 No 1 Tahun 2018

Alodiea Yoeantafara1 , S.M.,(2017). Pengaruh Pola Makan Terhadap Kadar Kolesterol Totalkesehatan Vol. 13 No.

Artiyaningrum, B.,(2015).Faktor-Faktor Yang Berhubungan Dengan Kejadian Hipertensi Tidak Terkendali Pada Penderita Yang Melakukan Pemeriksaan Rutin Di Puskesmas Kedungmundu Kota Semarang Tahun 2014. P. 4.

Clarasinta, C.,(2018).Hubungan Asupan Serat Dan Indeks Masa Tubuh (Imt) Dengan Kadar Kolesterol Total Pada Mahasiswa Jurusan Biologi Universitas Lampung.

Emira Tasya Ramadhani1, Y.S.,(2015).Hubungan Kasus Obesitas Dengan Hipertensi Di Provinsi Jawa Timur Tahun 20152016. Jurnal Berkala Epidemiologi. Volume 6 Nomor 1 (2018) 35-42.

Eriana, I.,(2017).Hubungan Gaya Hidup Dengan Kejadian Hipertensi Pada Pegawai Negeri Sipil Uin Alauddin Makassar Tahun 2017

Hasanudin1), V.M.A., Pertiwi Perwiraningtyas,(2018).Hubungan Aktivitas Fisik Dengan Tekanan Darah Pada Masyarakat Penderita Hipertensi Di Wilayah Tlogosuryo Kelurahan Tlogomas Kecamatan Lowokwaru Kota Malang. Volume 3, Nomor 1, 2018.

Kallo, N.A.K.F.O.V.,(2018).Hubungan Aktivitas Fisik Dengan Derajat Hipertensi Pada Pasien Rawat Jalan Di Wilayah Kerja Puskesmas Tagulandang Kabupaten Sitaro. EJournal Keperawatan (E-Kp) Volume 6 Nomor 1, Mei 2018.
Lestari, T.W.,(2015).Hubungan Kadar Kolesterol Dengan Tekanan Darah Pada Pra Lansia Hipertensi Di Posyandu Lansia Dusun Jetis Bantul Yogyakarta.

Mariya Ulfah1, H.S., Afiatin3,(2017).Hubungan Kadar Kolesterol Total Dengan Tekanan Darah Pada Masyarakat Jatinangor. Jsk, Volume 3 Nomor 2 Desember Tahun 2017.

Nst, A.R.,(2014).Prevalensi Dan Karakteristik Hipertensi Pada Remaja Usia 12-17 Tahun Yang Orangtuanya Normotensi Dan Hipertensi Di Perumnas Mandala Medan Pada Juli - September 2014

Pudiastuti, R.D.,(2011).Penyakit Pemicu Stroke Ed.N Medika.

Ramadhan, M.,(2017).Faktor Yang Berhubungan Dengan Kejadian Diabetes Mellitus Di Rsup Dr Wahidin Sudirohusodo Dan Rs Universitas Hasanuddin Makassar Tahun 2017

Rampan, L.,(2018).Faktor-Faktor Yang Berhubungan Dengan Kejadian Hipertensi Pada Lansia Tipe Ii Di Posyandu Lansia Di Wilayah Kerja Puskesmas Ge'tengan Kec. Mengkendek Kab. Toraja Utara

Ridwan, M.,(2002).Mengenal Mencegah Mengatasi Silent Killer Hipertensi

Rizma, A.,(2017).Hubungan Asupan Serat Dengan Kadar Kolesterol Total Pada Pria Dan Wanita Dewasa Di Posbindu Purwobakti Husada Kota Surakarta. Kesehatan

Rustiana,(2014).Gambaran Faktor Resiko Pada Penderita Hipertensi Di Puskesmas Ciputat Timur Tahun 2014

Selatan, S.,(2015) Ringkasan Eksekutif Data Dan Informasi Kesehatan.badan litabangkes, Kementrian Kesehatan, 2013

Sugiharto, A.,(2014).Faktor-Faktor Risiko Hipertensi Grade Ii Pada Masyarakat. 
Wungouw, H., S.H. Naue, And V. Doda,(2016).Hubungan Kadar Kolesterol Total Dengan Tekanan Darah Pada Guru Di Smp 1 \& 2 Eben Haezar Dan Sma Eben Haezar Manadoe- Biomedik (Ebm), . Volume 4, Nomor 2, Juli-Desember 2016. 